ISSN: 2614-1280, http://www.jurnal.stie-aas/ijebar

\title{
THE GUIDANCE OF TECHNOPRENEURSHIP USING EXPERT SYSTEM COMPUTING APPROACH BASED ON ENTREPRENEURIAL VALUES AND MULTIPLE INTELLIGENCES
}

\author{
Indra Hastuti ${ }^{1)}$, Singgih Purnomo ${ }^{2)}$, Wiji Lestari ${ }^{3)}$ \\ ${ }^{1,2,3}$ STMIK Duta Bangsa Surakarta, Indonesia
}

\begin{abstract}
: This study aims to build the Guidance of technopreneurship, especially Information Technology (IT) technopreneurship using expert system approach based on entrepreneurial values and multiple intelligences. The research consists of several steps : system analysis and design, system development and test and implementation system. The result is the guidance of technopreneurship using an expert system. Expert system consists of expertise domain, knowledge representation, rules, and input and output data. Data input consists of indicators of entrepreneurial values and multiple intelligences. The data output consists of conformity with 8 IT tecnopreneurships ie Software Application Developer, Data Analyst, System Analyst, Software Engineering, Computer Network Engineer, Graphics Designer \& Animator, Multimedia System Developer and Embedded \& Computer System Engineer.he test results with internal testing and external testing show the system works well.
\end{abstract}

Keyword $\quad$ : Guidance;Technopreneurships; Information Technology Expert System; Entrepreneurial Values; Multiple Intelligences

\section{Introduction}

Information

technology

(IT)

technopreneurship is growing rapidly in accordance with the progress of information and communication technology. Technopreneurship is the key to economic development in a country (Pawitan et al., 2017). The students are the youth generation who will become future leaders and assets of the nation's resources. The Students need to be directed and mentored for the future, business and technopreneurships be an alternative for them. The student's potential to become a businessman and technopreneur is influenced by various factors (Dutshe et al., 2013; Kamarudin et al., 2013; Rosly et al., 2015). The Various institutions such as government, campus and other institutions make efforts to increase the interest of students or young generation to entrepreneurships, business and technopreneurships(Dutshe et al, 2013; Son et al., 2016; Mirzanti et al., 2017).

The career selection is not an easy thing for students (Haji et al. 2014).The students in determining career in fututure need guidance and consultation.IT Technopreneurs become one of the student career alternatives. The Career guidance for students should be done according to student characteristics (Bilon, 2013; Purnomo et al., 2016). The system for guidance and student career consultation are implemented with various model and methods.there are the guidance sistem methods with manual or computation. The career guidance based on computing can use expert system, data mining, soft computing and others. Computing with expert systems can be used for the career guidance (Haji et al. 2014; Waghmode \& Jansandekar, 2015). 
ISSN: 2614-1280, http://www.jurnal.stie-aas/ijebar

In this research we build an IT technopreneurships Guidance system using Computation with expert system approach based on Students Personal Characteristics.In this research IT technopreneurships is divided into 8 types namely Software application developer, Data analyst, System analyst, Software Engineer, Computer network engineer, Graphics Designer \& animator, multimedia System developer and Embedded System \& Computer System Engineer (Singgih et al., 2016). Students personal characteristics that will be used are entrepreneurial values character and multiple intelligences.

\section{Literature Review}

\subsection{Entrepreneurship and}

\section{Technopreneurship}

The technopreneurship are part of the entrepreneurship.Technopreneurship is a type of entrepreneurship that combine with technological ability.development of entrepreneurship interest, including technopreneurship in the young generation by improving entrepreneurial spirit. There are 2 kind of entrepreneurial spirit namely entrepreneurial attitude dan entrepreneurial activities (Pawitan et al., 2017). The spirit and character Technopreneur are formed 3 main component that is intrapersonal, interpersonal and extrapersonal.The intrapersonal and interpersonal are components of the soft skill factor, while extrapersonal is the ability to be able to utilize both softskill components widely (Depdinas, 2008).

The entrepreneurial theory and practice should be developed with the concept of social enterprises and address social problems by applying holistic scientific principles and thinking system (Trivedi \& Misra, 2015).the development of entrepreneurship and teknopreneursip need to be done by various institution with various policy (Dutshe et al,
2013; Kamarudin et al., 2013; Rosly et al., 2015; Abdad \& Wahab, 2016).

Information technology

technopreneurship is technopreneurship that uses IT skill and ability. There are many types of IT technopreneurship among them are Software application developer, Data analyst, System analyst, Software Engineer, Computer network engineer, Graphics Designer \& animator, multimedia System developer, Embedded System \& Computer System Enginee and others (Singgih et al., 2016).

\subsection{Career Guidance}

Career Counseling and Guidance should be done with a multidisciplinary framework, such as psychology, sociology, education science, human resource management, andragogy and consellogy. The career conselling relates with scholar identify with various factors and characteristics. Framework of career conselling are Contuctivism Framework, Dialogical Self Theory, The Chaos Theory, Sociological theory, Coselogy framework (Bilon, 2013). Personal traits and emotional intelligence that affect Entrepreneurial Intention. The most influential factors of both is the need of achievement (dehkordi et al., 2012).

\subsection{Expert system}

Intelligent computing is a computer programming paradigm that tries to approach human intelligence. The most popular intelligent computing today is the expert system.Expert system is software application for decision making or problem solving that can achieve a level of performance that approaches human experts. The expert system compiled by the development environment and consultation environmen. part of the development environment relates to the expert domain while the consultation environment is related to the users (Turban, 1992).

The expert system is widely used in all aspects of life.The Expert system is used for 
ISSN: 2614-1280, http://www.jurnal.stie-aas/ijebar

career selection in secondary to higher education (Waghmode \& Jansandekar, 2015).The expert system application with multi expert system method based on multi agent paradigm and semantic webfor educational and career guidance (Haji et al. 2014).Expert system with a learning engine system that functions to form a new dynamic rule used in Power Plant with Distributed Control system (DCS) (Kaimal et al., 2014). Expert system is used as a Mathematics learning system for students with concept efect relationship (CER) which can facilitate learning (Salekhova et al., 2013).expert ystem is used for more effective expert advice with incomplete data or inputs (particular field). Expert system colsulting can save time, cost, easy to use, easy access and can consult with expertise from many experts (Saif et al., 2014). Web based expert system as a tool for the process decision making is used to identification for the selection of trust trading partners (Aziz, 2015).

\section{Research Methods}

This research is a modified research and development type. Research and development is a process or steps to develop a new product or to improve an existing product that can be accounted. In this research developed system application for Guidance IT tchnopreneurship with expert system computing approach based on Entrepreneurial Values and Multiple Intelligences. With the research flow as follows:

Figure 1: Flow Diagram of the Research

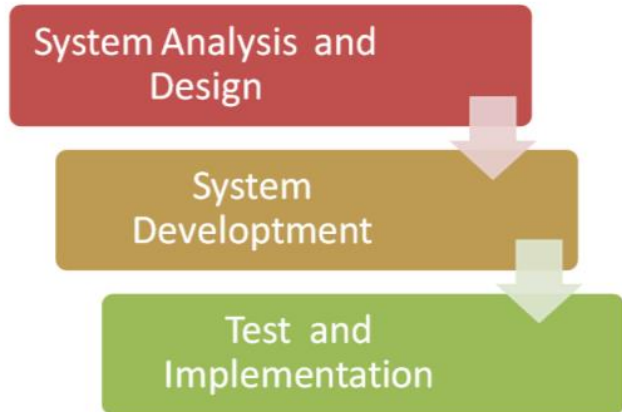

\subsection{System Analysis and Design}

At this step carried out system requirement analysis and design. The requirement analysis related to the data input of characteristics personal students. In the research characteristic personal students using parameters Entreprenurial Values and Multiple Intelligences. As for the output contains 8 IT Technopreneurship that is Software Application Developer, Data Analyst, System Analyst, Software Engineering, Computer Network Engineer, Graphics Designer \& Animator, Multimedia System Developer and Embedded \& Computer System Engineer.

The Inventory data input using questionnaire consisting 17 indicators with 5 scale answers. Inventory data inputs Entrepreneurial Values consists of Independent, Creative, Dare to Take Risks, Action Oriented, Leadership, Hard Work, Disappointing, Commitment, Realistic, Sense of Know, Communicative, Motivation for Success. Multiple Intelligences inventory using Gardner's Multiple Intelligences Scale consisting of 40 indicators with 5 answer scales. Multiple Intelligences consist of Visual Spatial, Logical Mathematics, Bodily Kinesthetics, Naturalist, Musical, Linguistic, Interpersonal and Intrapersonal. 
International Journal of Economics, Business and Accounting Research (IJEBAR)

Peer Reviewed - International Journal

Vol-2, Issue-3, 2018 (IJEBAR)

ISSN: 2614-1280, http://www.jurnal.stie-aas/ijebar

Table 1:List of Inventory Data Input

\begin{tabular}{|c|l|l|}
\hline No & \multicolumn{1}{|c|}{$\begin{array}{c}\text { Inventory Data } \\
\text { Input }\end{array}$} & \multicolumn{1}{|c|}{ Indicators } \\
\hline 1 & Entrepreneurial Values & $\begin{array}{l}\text { Independent (1 indicator), Creative (1 indicator), Dare } \\
\text { to Take Risks (1 indicator), Action Oriented (1 } \\
\text { indicator), Kepemimpinan (1 indicator), Hard Work (1 } \\
\text { indicator) Disappointing (Ulet) (1 indicator), } \\
\text { Commitment (1 indicator), Realistic (1 indicator), } \\
\text { Sense of Know (1 indicator), Communicative (1 } \\
\text { indicator), Motivation for Success (1 indicator) }\end{array}$ \\
\hline 2 & Multiple Intelligences & $\begin{array}{l}\text { Visual Spatial (5 indicators), Logical Mathematics (5 } \\
\text { indicators) Bodily Kinesthetics (5 indicators), } \\
\text { Naturalist (5 indicators), Musical (5 indicators), } \\
\text { Linguistic (5 indicators), Interpersonal (5 indicators) } \\
\text { and intrapersonal (5 indicators). }\end{array}$ \\
\hline
\end{tabular}

\subsection{System Developtment}

System development method using system development life cycle (SDLC) approach. The Guidance system for Technopreneurship by using expert system computing approach based on Entrepreneurial Values and Multiple Intelligences. This system consists of expert domain, knowledge representatition, rules and user interface.Expertise domains in this system are IT businessman, IT technopreneur, IT academic and business / management. The mettods how to get data from the expertise domain are by interview, questionnaire and observation. The result of the expert domain is used to make the knowledge representation by using the frame. Sample frames for Software Application Development as in table 2.

Table2: Frame of Software Application Development

\begin{tabular}{|c|c|}
\hline SLOT & FILLERS \\
\hline Entrepreneurial Values & $\begin{array}{l}\text { Independent (similar), Creative (similar), Dare to } \\
\text { Take Risks (similar), Action Oriented (similar), } \\
\text { Kepemimpinan (similar), Hard Work (similar), } \\
\text { Disappointing (similar), Commitment (similar), } \\
\text { Realistic (similar), Sense of Know (similar), } \\
\text { Communicative (similar), Motivation for Success } \\
\text { (similar). }\end{array}$ \\
\hline Multiple Intelligences & 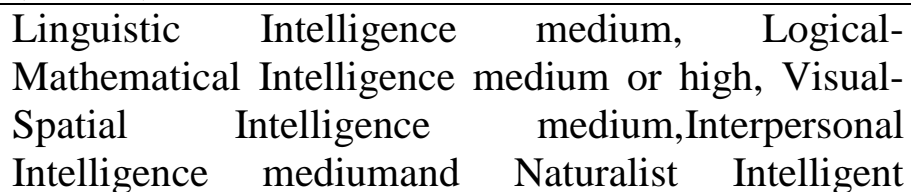 \\
\hline
\end{tabular}


International Journal of Economics, Business and Accounting Research (IJEBAR)

Peer Reviewed - International Journal

Vol-2, Issue-3, 2018 (IJEBAR)

ISSN: 2614-1280, http://www.jurnal.stie-aas/ijebar

medium.

The rules of the guidance system is based on the frame that is formed. There are 8 rules that match the 8 Information Technology (IT) Technopreneurship that is Software Application Developer, Data Analyst, System Analyst, Software Engineering, Computer Network Engineer, Graphics Designer \& Animator, Multimedia System Developer and Embedded \& Computer System Engineer. The rules are shown at table 3:

Tabel 3:Rules of System

\begin{tabular}{|c|c|}
\hline RULE 1 & $\begin{array}{l}\text { IF Entrepreneurial Values are similarAND Linguistic Intelligent is } \\
\text { medium AND Logical-Mathematics Intelligence is medium or high AND } \\
\text { Visual-Spatial Intelligence medium AND Interpesonal Intelligence } \\
\text { medium AND Naturalist Intelligence medium THEN Software } \\
\text { Application Developer }\end{array}$ \\
\hline RULE 2 & $\begin{array}{l}\text { IF Entrepreneurial Values are similarANDLinguistics Intelligece medium } \\
\text { AND Logical-Mathematics Intelligence medium or high AND } \\
\text { Interpesonal Intelligence medium THEN Data Analyst }\end{array}$ \\
\hline RULE 3 & $\begin{array}{l}\text { IF Entrepreneurial Values are similar ANDLinguistics Intelligece } \\
\text { medium or high AND Logical-Mathematics Intelligence medium or high } \\
\text { AND Visual-Spatial Intelligence medium AND Musical Intelligence } \\
\text { medium AND Interpesonal Intelligence medium AND Naturalist } \\
\text { Intelligence medium THEN System Analyst }\end{array}$ \\
\hline RULE 4 & $\begin{array}{l}\text { IF Entrepreneurial Values are similar ANDLinguistics Intelligece } \\
\text { medium or high AND Logical-Mathematics Intelligence medium or high } \\
\text { AND Visual-Spatial Intelligence medium AND Musical Intelligence } \\
\text { medium AND Interpesonal Intelligence medium AND Naturalist } \\
\text { Intelligence medium THEN Software Engineer }\end{array}$ \\
\hline RULE 5 & $\begin{array}{l}\text { IF Entrepreneurial Values are similar ANDLinguistics Intelligece } \\
\text { medium or high AND Logical-Mathematics Intelligence medium or high } \\
\text { AND Visual-Spatial Intelligence medium AND Body-Kinesthetics } \\
\text { Intelligence medium AND Interpesonal Intelligence medium AND } \\
\text { Naturalist Intelligence medium THEN Computer Network Engineer }\end{array}$ \\
\hline RULE 6 & $\begin{array}{l}\text { IF Entrepreneurial Values are similar ANDLinguistics Intelligece } \\
\text { medium or high AND Visual-Spatial Intelligence medium or high AND } \\
\text { Body-Kinesthetics Intelligence medium AND Musical Intelligence } \\
\text { medium AND Interpesonal Intelligence medium AND Naturalist } \\
\text { Intelligence medium THEN Graphics Desaigner \& Animator }\end{array}$ \\
\hline RULE 7 & $\begin{array}{l}\text { IF Entrepreneurial Values are similar ANDLinguistics Intelligece } \\
\text { medium AND Visual-Spatial Intelligence medium or high AND Body- } \\
\text { Kinesthetics Intelligence medium AND Musical Intelligence medium } \\
\text { AND Interpesonal Intelligence medium AND Naturalist Intelligence } \\
\text { medium THEN Multimedia System Developer }\end{array}$ \\
\hline RULE 8 & IF Entrepreneurial Values are similar AND Linguistics Intelligence \\
\hline
\end{tabular}


ISSN: 2614-1280, http://www.jurnal.stie-aas/ijebar

\begin{tabular}{|l|l|}
\hline medium AND Logical-Mathematical Intelligence medium or high AND \\
Visual-Spatial Intelligence medium AND Body-Kinesthetics Intelligence \\
medium AND Musical Intelligence medium AND Interpesonal \\
Intelligence medium AND Naturalist Intelligence medium THEN \\
Embeded \& Computer System Engineer \\
\hline
\end{tabular}

\subsection{Test and Implementation}

Test of the reaearch consist of internal test and external test. Internal test consists of white box test and white box test. External test consists of expertise judgment test and user acceptance test. Implementation step of the system is implemented to test sistem whether it is running well. Implementation of the use of a guidance system to a group of IT Students.

\section{Result And Discussion}

This research builds the guidance system technopreneurship using expert system approach based on entrepreneurial values and multiple intelligences. Arsitektu system built as in figure 2 below:

Figure 2: Architeture of Guidance System

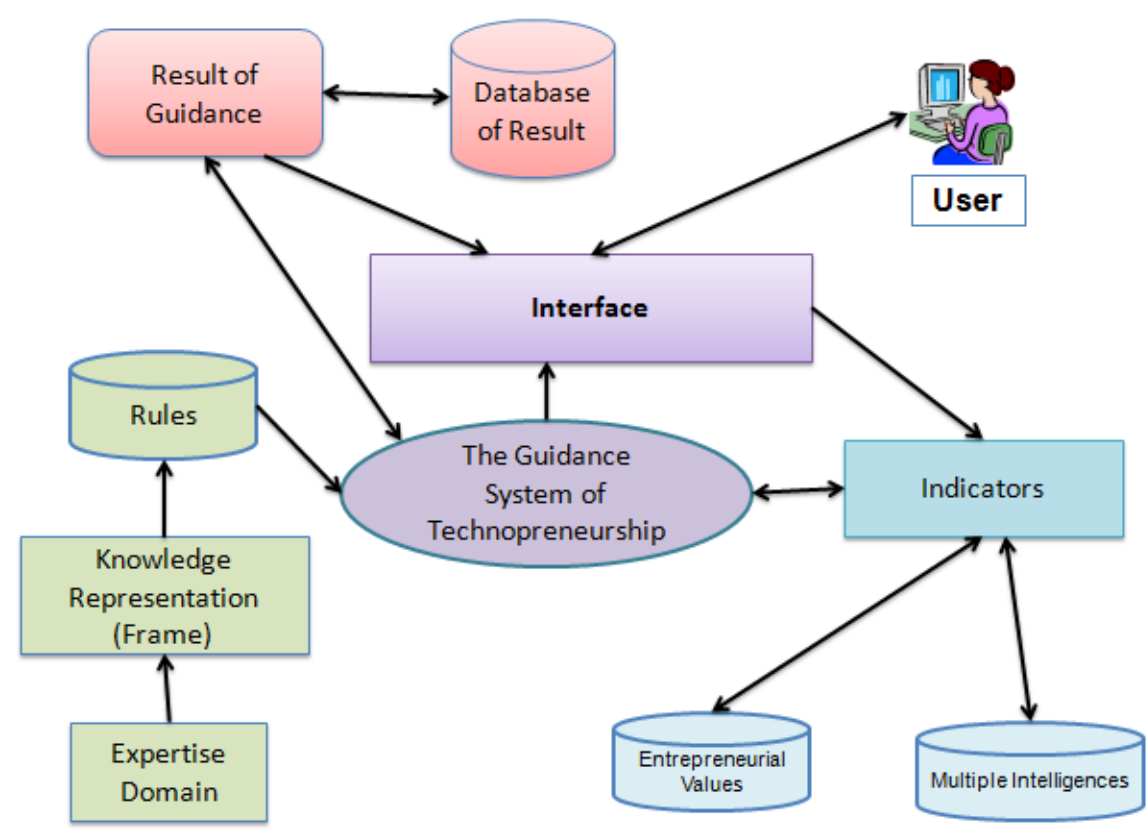

User give input data of Entrepreneurial Values and Multiple Intelligences through interface. The input data are used as indicators of Entrepreneurial values and multiple intelligences parameters and are stored in the database. Entrepreneurial values database and multiple intelligences user will be used for guidance process. Expert domains provide the knowledge that is replicated by the knowledge reprentation which is then created rules and stored in the database rules. The Guidance of technopreneuship process involves rules and Entreprenuerial Values and Multiple Intelligences 
International Journal of Economics, Business and Accounting Research (IJEBAR)

Peer Reviewed - International Journal

Vol-2, Issue-3, 2018 (IJEBAR)

ISSN: 2614-1280, http://www.jurnal.stie-aas/ijebar

indicators. This process generates the output stored in the databaseof result. User can see result of guidance through interface.Te Guidance System uses expert system computing wih interface shown in figure 3 bellow :

Figur 3: Examples of Interface Guidance System

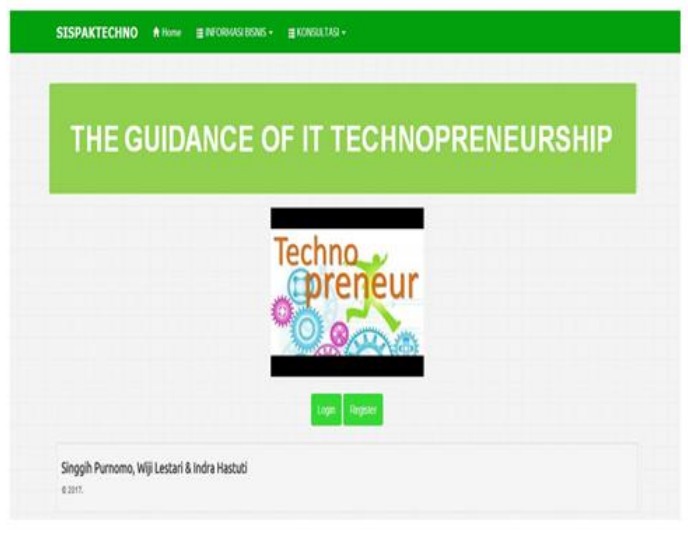

Internal testing is done with Black Box test and White Box test. Black box testing is done to ensure that an input or enter will run the appropriate process and produce output according to the system design. White Box testing is a test case design method that uses a procedural control control structure to obtain a test case. Flowchart on white box testing on this system the value of $\mathrm{CC}$ (Cyclomatic Complexity) obtained value less than 3 which means the program is not complicated.

The of external testing consist of user acceptance test and expert judgment test. The result of user acceptance test which consist of usage, navigation and display is $89 \%$. The test results with expertise judgment test consist of computational aspect and technopreneurship guidance aspect. The computing aspect get score $84.5 \%$ and technopreneurship guidance aspect get score $90 \%$. The results of external testing show that the system will be running well for use.

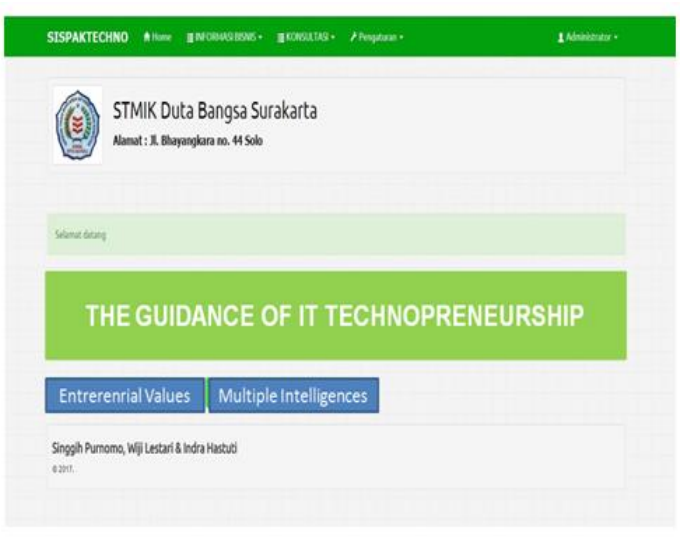

\section{Conclusion}

The students and the younger generation should be encouraged to entrepreneurship, including being technopreneur. information technology is growing rapidly. it is opening the opportunity to become technopreneur in the field of information technology. The Students or the younger generation in determining their potential to become a technopreneurship need guidance and consultation. In this research built the guidance system of technopreneurship by using expert system computing approach based on Entrepreneurial Values and Multiple Intelligence.There are 8 IT technopreneurship in the systemSoftware Application Developer, Data Analyst, System Analyst, Software Engineering, Computer Network Engineer, Graphics Designer \& Animator, Multimedia System Developer and Embedded \& Computer System Engineer.

The research built the Technopreneurship Guidance System with expert system approach. The expert system consists of expertise domains derived from IT businessman, IT technopreneur, IT and business / management academics. Result from expertise domain is used to create 
ISSN: 2614-1280, http://www.jurnal.stie-aas/ijebar

knowledge representation. Knowledge representation is used to create rules. In this system made 8 rules in accordance with the number of IT technopreneurship available. Input data comes from the score indicator entrepreneurial values and multiple intelligences. Indicators for Entrepreneurial Values consist of Independent, Creative, Dare to Take Risks, Action Oriented, Leadership, Hard Work, Disappointing), Commitment, Realistic, Sense of Know, Communicative, Motivation for Success. Indicators for Multiple Intelligences are Visual Spatial (Logical Mathematics, Bodily Kinesthetics, Naturalist, Musical, Linguistic, Interpersonal and Intrapersonal. Input data processed by rules with expert system approach will produce the appropriate IT Technopreneurship output.

The results of internal and external testing show that this system can be used as a Guidance System for technopreneurship, especially IT technopreneurship for students based on entrepreneurial values and multiple intelligences.

\section{References}

Abdad, S.N.A. \& Wahab, K.A. (2016). The Relationship Between Corporate Entrepreneurships and Firm Performance: Evidence from Malasyian Large Companies.International Journal Business and Society, 17(2), pp. 259-280.

Aziz, N.A.B. (2015). Web Based Expert System to Identify Trusted Partner for B2B Collaboration.Journal of Theoritical and Applied Information Technology, 79(3), pp. 365-369.

Bilon, A. (2013) Career Conselling : Current trend in Research and Theory.Journal of Consellogy, ISSN : 2299-4971

Dehkordi, A.M., Sasani, A. \& Fathi, M.R. (2012). Investigating the Effect of Emotional Intelligence and Personality Traits on Entrepreneurial Intention Using
The Fuzzy DEMATEL Methods, International Journal Bussiness and Social Sciences, 3(13), pp. 286-296.

Depdiknas. (2008). Technopreneurship.

Direktorat Akademik, Direktorat

Pendidikan Tinggi, Departemen Pendidikan Nasional.

Dutshe, A.Y., Ningi, S.I., Bakar,S.A. (2013). Technopreneurships and Entreprise Growth in Nigeria: An Exploration into the Latent Role of Microfinance Banks.IOSR Journal Business and Management (IOSR-JBM), 12(2), pp. 2532

Kaimal, L.B., Metkar, A. R., \&Rakesh, G.

(2014) Self Learning Real Time Expert

System, International Journal on Soft

Computing, Artificial Intelligence and

Application (IJSCAI), 3(2), pp.13-25

Kamarudin, H.S.,\& Sajilan, S. (2013). Critical Succes Factors of Technopreneurships in the Creative Industry : A Study of Animation Ventures. Review of Intregrative Business \& Economy, 2(1), pp. 1-37

Mirzanti, I.R., Simatupang, T.M., Larso, D., \& Dohar Bob M. Situmorang, D.B.M. (2017). Needs Evaluation of Entrepreneurship Policy at the AgendaSetting Stage.International Journal Business and Society, Vol. 18, S2, pp. 279294.

Pawitan, G., Nawangpalupi, C.B., \& Widyarini, M. (2017). Understanding the Relationship Beetwen Entrepreneurial Spirit and Global Competitiveness: Implications for Indonesia. International Journal Business and Society, Vol. 18, S2, pp. 261- 278.

Purnomo, S., Lestari, W. \& Hastuti, I. (2016). The Mapping of Information Tecnology (IT) Technopreneurships Based of Learning Styles and Multiple Intelligences.International Conference of Education and Technology for Empowering Agents of Change, 1(1),ISSN 
ISSN: 2614-1280, http://www.jurnal.stie-aas/ijebar

2541-1578 November 2016. Proceeding of International Seminar, Fakultas Keguruan dan Ilmu Pendidikan, Universitas Kristen Satya Wacana Salatiga, Central java, Indonesia.

Rosly, H.E., Junid, J., Lajin, N. F. M., \& Rahim, H.L. (2015). The relationship of Creativity and Technopreneurship Intention. International Academic research Journal of Social science, 1(1), pp. 8-15.

Salekhova, L., Nurgaliev, A., Zaripova, R.,\&Khakimullina, N. (2013) The Principles Designing an Expert System in Teaching Mathematics, Universal Journal of Education Research, 1(2), pp. 42-47.

Son, J.J., Liem, H.E., \& Ahmad, S.A. (2016). Be Your Own Boss, Anyone? Earning, Employment, Changes and Job Choice of Fresh University Graduates.International Journal Business and Society, 17(2), pp. 511-520.
Saif, S.M., Hamid, H.E.C., Abdulsalam, R.M.A., \&Ibrahim, J.B. (2014).

Professional Practise : Use of Expert system in Providing Consulting service, International Journal of Information and Communication Technology Research, 4(5), pp. 195-199.

Trivedi, C. \& Misra,S. (2015). Relevance of System Thinking and Scientific Holism to Social Entrepreneurships.The Journal of Entrepreneurships, 24(1), pp. 37-62

Turban, E. (1992). Expert System and Applied Artificial Intelligence. Macmillan Publishing Company, New York.

Waghmode, M.L.\& Jansandekar, P.P. (2015). A Study Expert System or Career Selection: Literature Review.Inernaional Journal of Anvanced Research in Coputer Science and Software Engineering, 5(9), pp. 778785, ISSN : 2277 128X 